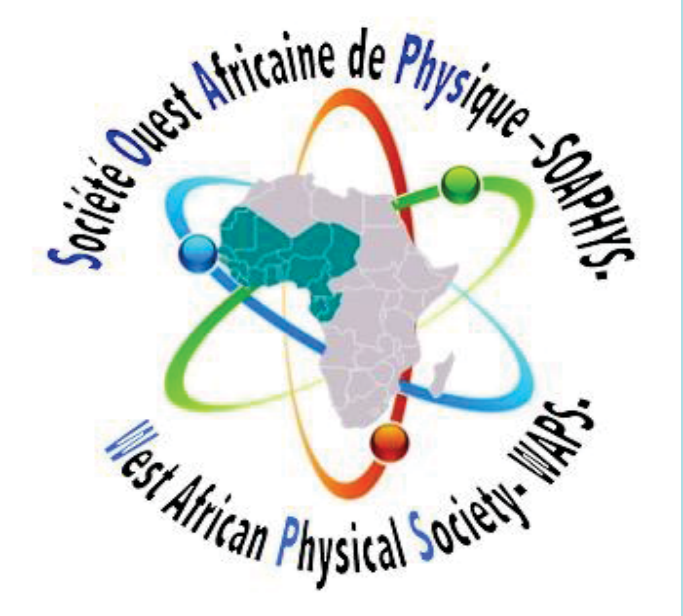

ISSN 2630-0958

Jourmal de Physique de la Soaphys J. P. Soaphys
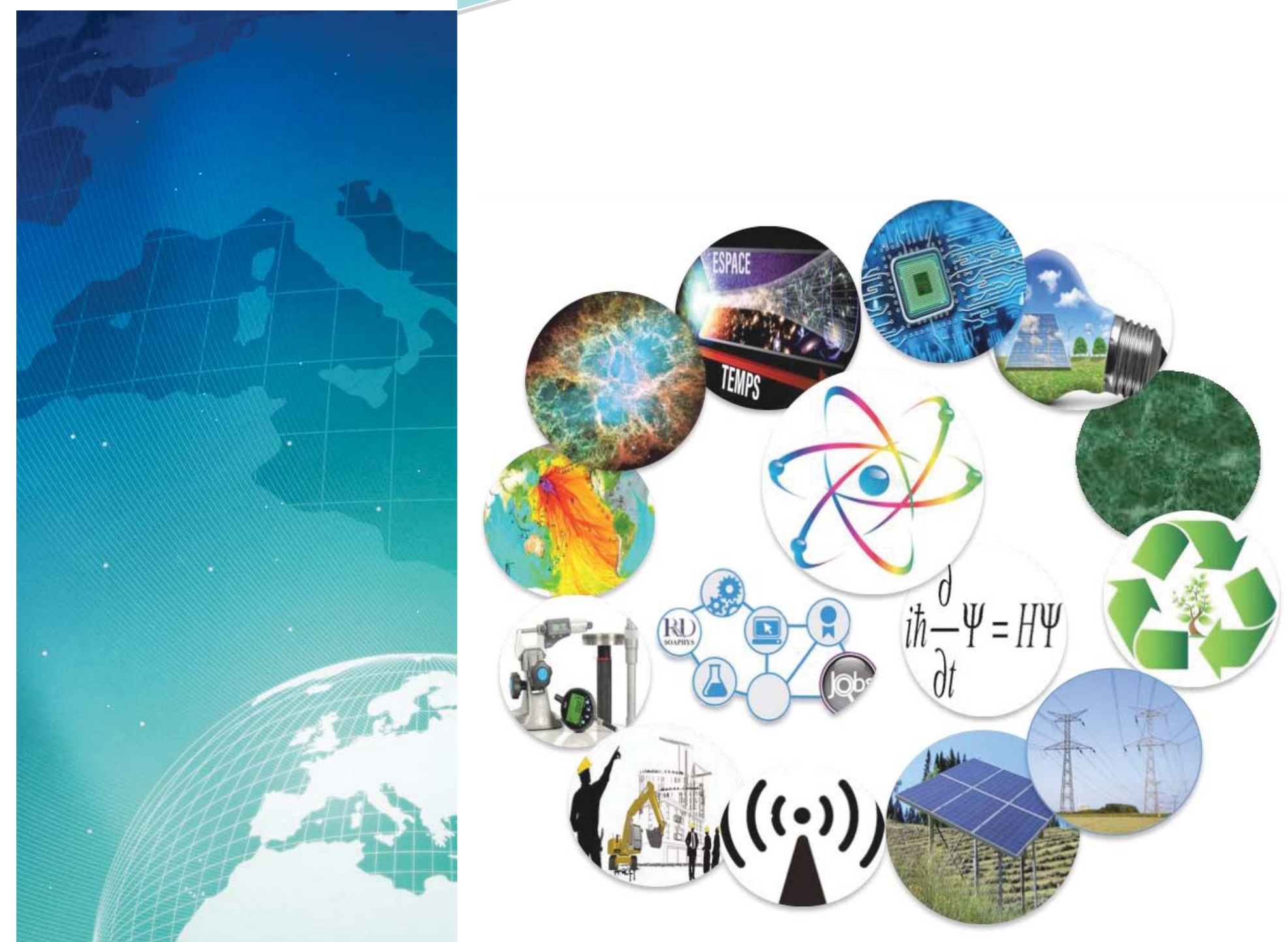

Volume 2, Numéro 1 - Décembre 2020 SOAPHYS ${ }^{\odot}$ 


\section{Journal de Physique de la Soaphys Volume 2, Numéro 1, Décembre 2020}

\section{Directeur de publication}

- Prof. Jean KOULIDIATI

\section{Comité scientifique}

- Prof. Jean CHABI OROU (Benin)

- Prof. Félix HONTINFINDE (Benin)

- Prof. Dieudonné Joseph BATHIEBO (Burkina Faso)

- Prof. Fréderic OUATTARA (Burkina Faso)

- Prof. Adama DIAWARA (Côte d'Ivoire)

- Prof. Vafi DOUMBIA (Côte d'Ivoire)

- Prof Abdramane BA (Mali),

- Prof. Badié DIOURTHE (Mali),

- Prof. Saïdou MADOUGOU (Niger)

- Dr. Haoua AMADOU, MC (Niger)

- Prof. Kossi NAPO (Togo)

- Prof. Magolmèèna BANNA (Togo)

- Prof. Oumar KA (Sénégal)

- Prof. Diouma KOBOR (Sénégal)

\section{Rédacteur en chef}

- Prof. Antoine BERE (Burkina Faso)

Rédacteur en chef adjoint

- Dr. Milohum Mikesokpo DZAGLI, MC, (Togo),

Secrétaire technique

- Dr. Sié Zacharie KAM, MA, (Burkina Faso) 


\section{Journal de Physique de la Soaphys Volume 2, Numéro 1, Décembre 2020}

\section{SOMMAIRE}

Analysis of extreme rains through climate indicators in the context of climate

$\mathrm{C} 20 \mathrm{~A} 1: 1-33$ change in southern Benin,

Hounvou et al.,

Comparative study of the power output of a mobile PV panel and a fixed PV

panel

Sène et al.,

Optimisation du rendement et de la température d'un capteur solaire plan à eau par simulation

Kanouté et al.,

Expérimentation et analyse thermique d'un concentrateur hémisphérique stationnaire sous les conditions climatiques à Ouagadougou, Burkina Faso Ouédraogo et al.,

Étude comparative de la digestion anaérobie entre pulpes de la pomme de cajou, bouse de vache et leur codigestion

Faye et al.,

Energy situation of Senegal: sub-sector of electricity

Ba et al.,

Low voltage grid connected three-phase inverter control with hybrid neuro-fuzzy Ndiaye et al.,

Assessment of different sands potentiality to formulate an effective thermal energy storage material (TESM).

Bagré et al.,

Évaluation de la dose aux patients lors de l'examen du thorax de face à Abidjan, Côte d'Ivoire

Konaté et al.,

Modélisation thermodynamique de combustion mono-zone de biodiesels dans un moteur diesel et estimation théorique des émissions potentielles

Dabilgou et al.,

Laboratory estimation of elemental and organic carbon emissions from advanced biomass stoves in Senegal

Kane et al.,

Exploitation du spectre de l'étoile HD149382 : approximation des paramètres physiques par une technique d'analyse spectrale Bado et al.,

Injection de puissance photovoltaïque au réseau électrique faible

Diaw et al.,

Assessing and modeling particulate pollution in the city of Ouagadougou

(Burkina Faso)

Ouarma et al., 


\title{
ENERGY SITUATION OF SENEGAL: SUB-SECTOR OF ELECTRICITY
}

\author{
Ba Amadou *, Ndiaye Alphousseyni, Traoré Mamadou and Mbodji Senghane \\ University Alioune Diop, Bambey, Sénégal \\ *amadou4.ba@uadb.edu.sn
}

\section{INFOS SUR L’A R T I C L E}

Historique de l'article:

Reçu le : 24 novembre 2020

Réçu en format revisé le 05 février 2021

Accepté le 07 février 2021

Keywords : Energy, Electricity, Power

Plant, Senegal, Solar, Wind and

Hydraulic

Mots-Clés: Energie, Electricité,

Centrale, Sénégal, Solaire, Eolien,

Hydraulique

\begin{abstract}
A B S T R A C T
Senegal's energy consumption is dominated by oil products and biomass. The electricity sub-sector, which accounts for only $10.4 \%$ of total energy consumption, far behind biomass $41.6 \%$ and oil products $39.2 \%$, is remains dominated by thermal units. The objective of this study is to do an analysis of the electricity sub-sector. It shows a dependence on imports of oil and gas to meet our demand. Important policies have been developed to think about energy independence by exploiting our renewable energies potential, $5 \mathrm{kWh}$ $/ \mathrm{m}^{2} /$ day for solar, average wind speed estimated at $4 \mathrm{~m} / \mathrm{s}$ for wind. The liberalization of the energy market has allowed public and private investors to invest in this sector. The installed capacity has enabled Senegal to avoid the emission of 156.243 tons of $\mathrm{CO}_{2}$ per year with the six solar photovoltaic plants. Despite immense potential of renewable energies, their rate remains low in the power park and is estimated for (solar photovoltaic, wind and hydraulic) at $28 \%$ in 2020.
\end{abstract}

\section{RE S U M E}

La consommation énergétique du Sénégal est dominée par les produits pétroliers et la biomasse. Le sous-secteur de l'électricité qui n'est que de 10,4 $\%$ de la consommation totale d'énergie, loin derrière la biomasse $41,6 \%$ et les produits pétroliers $39,2 \%$ reste dominer par les unités thermiques. L'objectif de cette étude est de faire une analyse sur le sous-secteur de l'électricité. Elle montre une dépendance vis-à-vis des importations des hydrocarbures pour satisfaire notre demande. Des politiques ont été élaborées pour penser à une indépendance énergétique en exploitant notre potentiel en énergies renouvelables, $5 \mathrm{kWh} / \mathrm{m}^{2}$ /jour pour le solaire, vitesse moyenne du vent estimée à $4 \mathrm{~m} / \mathrm{s}$ pour l'éolien. La libération du marché de l'énergie a permis aux investisseurs publics et privés d'investir sur ce secteur. La capacité installée a permis au Sénégal d'éviter l'émission de 156,243 tonnes de $\mathrm{CO}_{2}$ par an avec les six centrales solaires photovoltaïques. Malgré un potentiel immense en énergies renouvelables, leur taux de pénétration reste faible et est estimé à $28 \%$ en 2020 pour le (solaire, éolien et hydraulique).

\section{INTRODUCTION}

The current global energy system depends on the use of fossil fuels. Coal, oil and gas represent almost $80 \%$ of primary energy consumption in the world. These fossil fuels are the primary source greenhouse gases emissions. Today, the average concentration of carbon dioxide $\left(\mathrm{CO}_{2}\right)$ in the atmosphere reached $407 \mathrm{ppm}$ in 2018, an increase of $2.2 \mathrm{ppm}$ compared to 2017 [WMO. 2020]. Global warming is a phenomenon of an increase in the average temperature of the oceans and the atmosphere on a global scale over several decades. The objectives of the COP21 (Paris Agreement) are to maintain the global average temperature at $1.5^{\circ} \mathrm{C}$ or 2
${ }^{\circ} \mathrm{C}$ [COP21]. In 2020, the global average temperature was $1.1^{\circ} \mathrm{C}$ and we are far from reaching this target at this rate. Since 1850 each decade has been warmer than the last and this phenomenon is only intensifying. The decade 2010 and 2020 showed by far the highest temperatures ever measured. Senegal is located in West Africa covering an area of $206.712 \mathrm{~km}^{2}$ and its population is currently estimated at 14 million is not spared this situation. In addition, its demographic growth rate is $2.87 \%$ per year [Tchanche et al., 2017] and this population will reach 22 million inhabitants by 2030 [Ba, 2018]. 
Faced to this boom demographic, major challenges have to be met such as access to energy, drinking water, facilitating the free movement of people and goods and the well-being of people. Development and improvement of the living conditions of the populations are at the heart of Senegal's policies. In reality, each country seeks to improve the well-being of its population by fighting against poverty and by developing desirable actions for a good living environment for its population. It can be said that access to energy is the first step towards socioeconomic development. With these recent discoveries of oil and gas, Senegal will be able to think about its autonomy in energy but the exploitation of gas will have to start in 2021 and of oil between 2021 and 2023 [Ndao, 2020]. Thus, an important part of the budget is currently being mobilized to supply energy and this negative trend should continue in the years to come, given our dependence on oil products. In fact, during a decade Senegal's oil invoice went from 184 billion FCFA in 2000 to around 400 billion FCFA in 2009 [Kébé, 2013]. In 2017 , it was estimated at 856 billion FCFA, with $60 \%$ of export incomes and $10 \%$ of PIB [Senegal's oil downstream]. This led to a strong outflow of currencies negatively influencing on the country's trade balance. Also, a significant portion of the budget is currently being mobilized to honor this invoice. This negative trend is expected to continue in the years to come, given our dependence on oil products.

However, faced with these issues such as global warming on the one hand and on the other hand the dependence on imports of oil products which weigh heavily on the trade balance, significant challenges must be met. Senegal is therefore moving towards harnessing its abundant renewable energy potential to secure its energy needs. Important reforms have been established:

Law No. 2010-21 which aims to promote the development of renewable energies throughout the territory of Senegal in 2010.

The energy sector politics and development letter created in 2012, which analyses is the national and international energy sector in order to reduce the energy dependence.

The Emerging Senegal Plan (PSE) launched in 2014 guarantees broad and reliable access to inexpensive energy aims to achieve the following objectives [Report, 2015]:

- have perfect availability of energy in sufficient quantity and quality;

- have one of the lowest electricity prices in the subregion (60 to $80 \mathrm{FCFA} / \mathrm{kWh}$ ) to support economic competitiveness;

- reduce household electricity bills;

- obtain a rate of $20 \%$ of renewable energies in power by 2017 .

All of these policies are part of securing energy supplies and reducing dependence on fossil fuel importations. Indeed, the objective of this study is to analyze the energy situation in particular the electricity sub-sector of Senegal. The advantage of this analysis is to better assess needs, to predict energy crises and to draw conclusions on the reforms already established for the development of the energy sector. This study is organized around these main sections. First, a state on energy consumption in Senegal is made. Then a study on renewable energy projects and finally the electricity sub-sector will be studied and to see the rate of renewable energies in the power plant.

\section{SENEGAL'S ENERGY SITUATION}

Senegal's energy consumption can be split into three subsectors: the electricity sub-sector; the biomass or domestic fuels sub-sector and the hydrocarbons subsector. The electricity sub-sector is only $10.4 \%$ of total energy consumption, far behind biomass $41.6 \%$ and oil products $39.2 \%$. Biomass and domestic fuels are mainly used in rural areas while large urban centers prefer charcoal which has a penetration rate of around $8.1 \%$ (Fig.1).

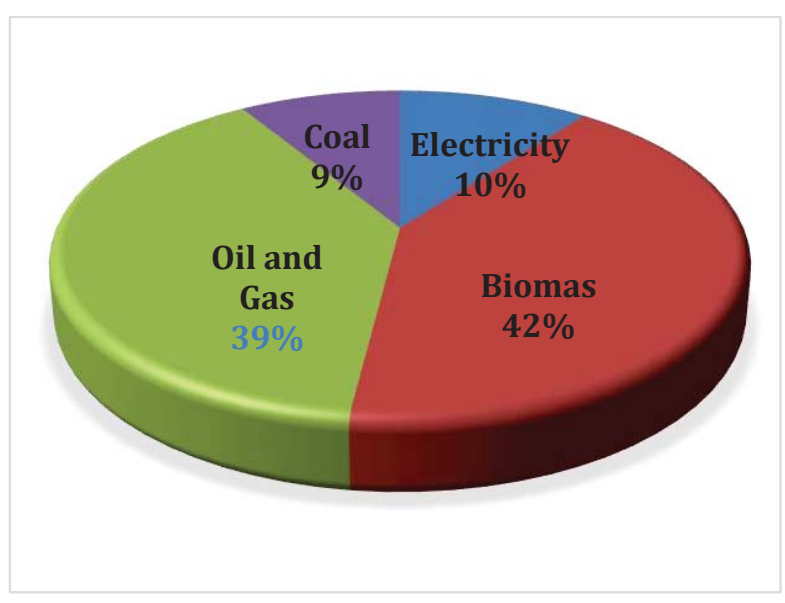

Fig.1. Energy consumption by source. [Ba, A, S., 2018]

Senegal's energy sector remains dominated by hydrocarbons and biomass and shows that it is a nonindustrialized country. Most of its energy consumption is dominated by biomass and oil products. This high rate of its products is widely used in the transport sector, which includes in transport way (airway, railway, maritime and road). The use of biomass (wood and charcoal) remains relatively high and is generally used in households as fuel. The consumption of coal is exclusively due to cement factories which use it in their kilns for cooking. This situation is explained by a lack of income of the population especially in rural areas having no other alternatives to meet their energy needs. However, this overexploitation of these resources constitutes a threat to the forest ecosystem [Cissokho et al, 2020]. In the remainder of this study, we will focus on the electricity sub-sector, which represents $10 \%$ of the country's energy consumption.

\section{STATES OF RENEWABLE ENERGY PROJECTS}

Faced with the situation of energy dependence which weighs heavily on our economy and the consequences of global warming, Senegal is committed to the promotion and development of renewable energies. The country has favorable potential and its exploitation could reduce our 
energy dependence. The average irradiation estimated at $5 \mathrm{~kW} / \mathrm{m}^{2} /$ day and 3000 hours of sunshine [Interim report Phase 1, 2010 and Thiam, 2015] and is fairly balanced throughout the year and varies from region to region (Table 1).

Table 1. Solar Irradiance per year

\begin{tabular}{|c|c|}
\hline Dakar & $2031 \mathrm{~kW} / \mathrm{m}^{2} /$ year \\
\hline Bambey & $2098 \mathrm{~kW} / \mathrm{m}^{2} /$ year \\
\hline Nioro du Rip & $2020 \mathrm{~kW} / \mathrm{m}^{2} /$ year \\
\hline Ziguinchor & $1779 \mathrm{~kW} / \mathrm{m}^{2} /$ year \\
\hline Kédougou & $2111 \mathrm{~kW} / \mathrm{m}^{2} /$ year \\
\hline Tambacounda & $1793 \mathrm{~kW} / \mathrm{m}^{2} /$ year \\
\hline Matam & $2030 \mathrm{~kW} / \mathrm{m}^{2} /$ year \\
\hline Lingère & $2116 \mathrm{~kW} / \mathrm{m}^{2} /$ year \\
\hline Podor & $1863 \mathrm{~kW} / \mathrm{m}^{2} /$ year \\
\hline Louga & $2017 \mathrm{~kW} / \mathrm{m}^{2} /$ year \\
\hline
\end{tabular}

However, the use of wind resources for electricity production is still low in Senegal and is mainly due to the lack of knowledge of the available potential. Studies have shown that Senegal has good wind potential on the coastal axis going from Sakhor to Gandon. The wind potential is very important with an annual average of wind speeds estimated at $4.80,4.32$ and $4.34 \mathrm{~m} / \mathrm{s}$ respectively in the sites of Potou, Kayar, Gandon at a height of $20 \mathrm{~m}$. For a height of $12 \mathrm{~m}$ we obtain in the sites of Sakhor, Sine Moussa Abdou, Botla, Dara Andal and Nguebeul respectively average speeds of $4.49,4.47,4.16,4.12$ and $4.36 \mathrm{~m} / \mathrm{s}$ [Bilal et al, 2013]. The hydraulic potential is abundant but its exploitation is limited. The countries bordering the Senegal River have set up the OMVS (Organization for the Development of the Senegal River) to better exploit this potential from hydroelectric dams. The exploitation of this source is not significant with the Manantali dam of capacity (200 MW) distributed $52 \%$ for Mali, $33 \%$ for Senegal and $15 \%$ for Mauritania. About ten dam sites with a hydroelectric potential estimated at more than $4.000 \mathrm{GWh} /$ year have been identified along the Senegal River and its tributaries according to the OMVS [PERACOD, 2011]. But their exploitation obeys technical and economic constraints which limit their development in developing countries. The site with adequate potential is often far from consumption centers, which contributes to further increase the investment costs. These energy sources are the most exploited for large-scale electricity production and have today contributed to the development of the energy mix. In recent years, important projects have been carried out in Senegal and have contributed to increasing the electricity production fleet. The liberalization of the energy market has enabled private producers to invest more in photovoltaic solar energy connected to the electricity distribution grid. In fact, important projects have been carried out over the past five years. The installation of the first solar power plant connected to the electricity grid began in Senegal in 2015-2016, quickly followed by five other projects. The Bokhol power plant with a capacity of 20 MW commissioned in 2016 in Bokhol in Saint Louis region by Synergy 2, it occupies an area of 50 hectares [Project, 2012]. In 2017, the Malicounda photovoltaic solar power plant in Thiès region, with a capacity of 20 MW of $11 \mathrm{MW}$ is operated, is the result of a contract concluded between SENELEC and Solaria, an Italian company. The investment cost is estimated at 22 billion FCFA francs, and occupies an area of 100 hectares. In the same year, two power plants of $30 \mathrm{MW}$ each were inaugurated in the region of Thiès. The Ten Mérina [Ten Merina Power plant, 2020] power plant occupies an area of 46 hectares and the power plant of Sinthiou Mékhé. In 2018, the Kahone plant in Kaolack and the Sakal plant in Louga of $20 \mathrm{MW}$ each are added to the four plants already in place. Now, the photovoltaic solar power plants connected to the grid in Senegal in operation have a capacity of $140 \mathrm{MW}$. Other projects are underway, such as the Kael (25 MW), Kahone (35 MW) and Diass (25 MW) power plant and could increase the installed solar capacity around 225 MW by 2021 [Report, 2018 and Interim report, 2020]. The idea of the first public utility wind farm in Senegal dates back to 2007. In 2013 the electricity purchase agreement was signed with SENELEC and it is in 2020 that the first wind power plant of $158 \mathrm{MW}$ is implanted in 2020 in Taiba Ndiaye region of Thiès. The plant is connected to the grid and is composed of 46 wind turbines [Taiba N'Diaye wind farm, 2020]. A large part of the population lives in rural areas and does not have access to electricity, so improving the living conditions of the populations is made one of the priorities of the Plan Senegal Emergent (PSE).

To facilitate access to electricity, the government of Senegal created ASER (Senegalese Rural Electrification Agency) in 2000. Its mission is to provide electricity companies and individuals with technical assistance and financial needed to support rural electrification.

Today the rural electrification rate is $43 \%$ [Regional offgrid electrification project, 2020] low compared to that of the urban which is $90 \%$, or about $57 \%$ of the rural population do not have access to electricity. The state of Senegal aims for universal access to electricity by 2025 to achieve the objectives defined in the PSE by 2030. For this, ASER plans to :

- extend the connection of the SENELEC network in rural areas

- electrification of remote villages by off-grid systems (mini-grids and individual solar systems).

Senegal is actively committed to universal access to electricity through hybrid mini-grids and this is the first in the ECOWAS zone with an achievement rate of $12 \%$ [Berthémaly et al]. In the perspective of universal access to electricity, projects are underway. ASER has set up a project to electrify 1000 villages by solar mini-grids financed by the State of Senegal, Green Climate Fund (GCF) and the West African Development Bank (BOAD). The 1000 villages are spread over seven regions: Kafrine, Kaolack, Fatick (in the Center), Kolda, 
Kédougou, Tambacounda (in the South) and Saint-Louis (in the North) [PNER, 2020]. Each village benefits from 15 to $45 \mathrm{kWp}$ power plant associated with low voltage (LV) grid according to demand. This project will provide access to electricity to 340.000 inhabitants. Senegal will be able to have universal access to electricity by 2025 by setting up major projects [Project PAP2, 2018] in the energy sector. The development of the rural world is further accentuated with access to energy. Photovoltaic systems are a lever to accelerate and contribute to the socio-economic development of isolated areas.

\section{SUB-SECTOR OF ELECTRICITY}

National electricity production was 1,249.29 MW in 2018 and is provided by the Senelec park with a total installed capacity of $444 \mathrm{MW}$, or $35.54 \%$ of the national park and the units of private producers with a capacity total of 805.29 MW or $56.64 \%$. Fig. 3 presents the total power installed in 2018.

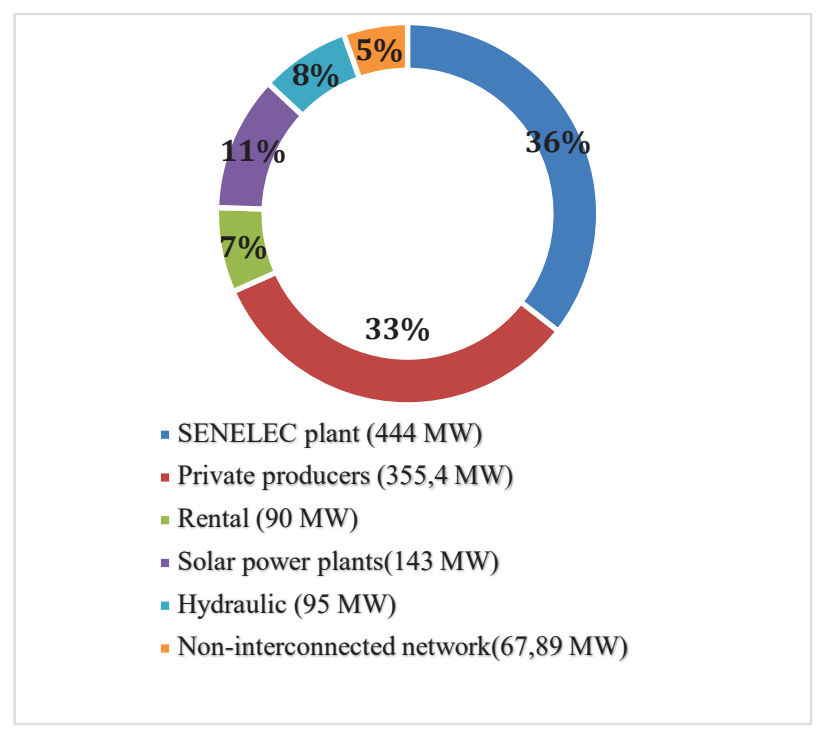

Fig.2. Power installed in 2018. [Repport annual 2018]

The production park Fig 2 is made up of SENELEC's own power plants, imports from Mauritania, independent production plants, photovoltaic solar power plants, rental, OMVS, the non-interconnected network and the automobile production. Fig. 2 shows that independent producers occupy an important place in the production of electricity. Their share rose from $28 \%$ in 2016 to $50 \%$ of the total installed capacity in 2020 [CRSE, 2020]. This production is strongly dominated by thermal units and shows its dependence on petroleum products. Senegal plans to increase the share of renewable energies in electricity production by 2030. Fig. 3 gives us the distribution of the power according to each technology.

Between 2017 and 2020 the predominance of thermal power decreased considerably and droped from $82 \%$ in 2017 to $72 \%$ in 2020 and is expected to reach $62 \%$ in 2030. This decrease is due to the development and massive involvement of solar and wind power, which increased from $10 \%$ for solar photovoltaic in 2017 to 22 $\%$ for solar and wind in 2020. In 2020, the park saw the arrival of three solar power plants in Diass, Touba and Kahone with respective powers of $25 \mathrm{MW}, 25 \mathrm{MW}$ and
35 MW. Today photovoltaic solar power plants have an estimated power of $225 \mathrm{MW}$ and a wind power plant of 157 MW power. In 2020 the share of renewable energies (solar photovoltaic, wind and hydraulic) is estimated at $28 \%$ [Rapport Senegal, 2020] and it is expected to increase to $38 \%$ by 2030 . In Senegal the emission factor (EF) is 0.637 tons of $\mathrm{CO}_{2}$ per (MWh) Mega Watt Hour in the interconnected network [Projet, 2012].

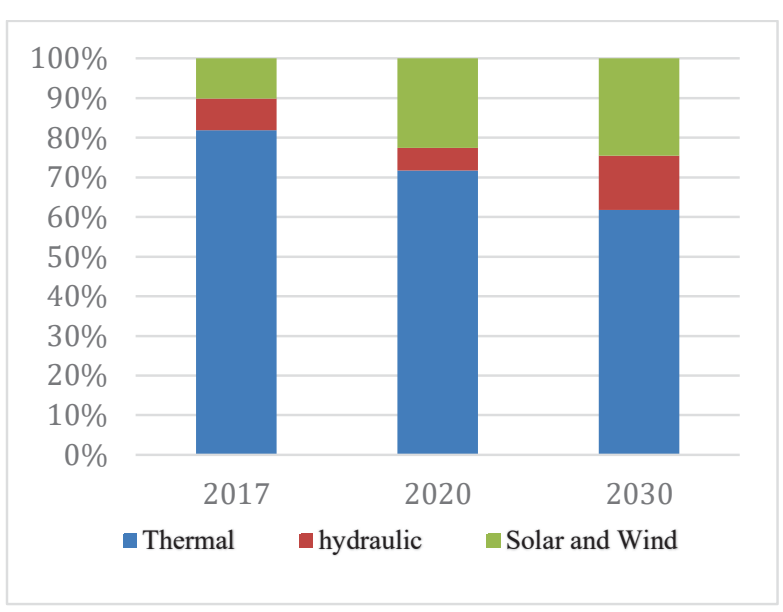

Fig.3. Installed power for each technology

In fact, in order to determine the amount of $\mathrm{CO}_{2}\left(Q_{\mathrm{co} 2}\right)$ avoided per year, it is necessary to go from the production capacity to the amount of energy taking into account the load factor estimated at $20 \%$ from equation 1 .

$$
\frac{Q_{c o 2}}{a n}=E F \times P_{\text {ins }} \times t \times 0.2
$$

Where

$\mathrm{t}$ : the time expressed in hour (h)

$P_{\text {ins }}:$ the installed power in megawatt (MW)

So, the installed capacity has enabled Senegal to avoid the emission of 156.243 tons of $\mathrm{CO}_{2}$ per year with the six solar photovoltaic plants. Despite this advantage of reducing atmospheric pollution, it should be noted that the installation of these power stations requires a large surface area so they have an impact on agriculture and livestock.

\section{CONCLUSION}

Senegal's energy consumption is highly dependent on oil products and biomass. Institutional reforms have been established for the development and improvement of the energy sector. They made it possible to increase the rate of rural and urban electrification to $43 \%$ and $90 \%$ respectively. In 2018, the rate of renewable energies in the energy mix was $10.43 \%$ against $20 \%$ set for 2017 et the $\mathrm{kWh}$ price of electricity is 106,89 FCFA. For universal access in 2025, the government must accelerate and multiply electrification projects based on renewable energy. Energy independence can be achieved only by adopting good policies on our oil and gas reversals and by exploiting our renewable energy potentials by setting up sustainable development projects. In oulook we propose some recommendations : 
- accelerate access to electricity through renewable energies to converge towards full coverage of the rural population,

- think on a project to build an electrical network based on renewable energies and,

- promote national engineering.

\section{REFERENCES}

WMO, 2020. Statement on the State of the Global Climate, available on:"https://www.actuenvironnement.com/media/pdf/news-35129etatmondial-du-climat-2020.pdf," consulté le 23/08/2020.

COP21, Accord de Paris, : "https://ec.europa.eu/clima/policies/international/ne gotiations/paris fr,"consulté le 23/08/2020.

Tchanche, B., Diaw, I, 2017. Analyse énergétique du secteur des transports du Sénégal, Conférence Ouest Africaine sur les Energies Renouvelables, Saint Louis (2017), 1-5.

Ba, A, S., 2018. Accès universel et durable à l'électricité au Sénégal : Les conditions du succès.

Ndao, F., 2020. La gouvernance des ressources pétrolières et gazières : Etat du débat et perspectives, $1-18$.

Kébé, A., 2013. Contribution au pré dimensionnement et au controle des unités de production d'énergie électrique en site isolé à partir des énergies renouvelables : Application au cas du Sénégal. Thèse de doctorat, Université Paris Sud.

Senegal's oil downstream, available on: www.energie.gouv.sn/distribution-aval/. Consulted in $22 / 08 / 2020$.

Report, 2015. Plan d'Actions National des Energies Renouvelables (PANER) SENEGAL Période [20159+4442020/2030], 08.

Ba, A, S., 2018. Analyse de la politique d'efficacité énergétique du Sénégal : Barrières et perspectives. Université Paris Dauphine, PSL Research University.

Cissokho, D., SY, O., et Ndiaye, L, G, 2020. Migrations et bois-énergie dans la ville de Bakel (Sénégal). Revue Canadienne de Géographie Tropicale, 6, 5-11.

Interim report Phase 1, 2010. Diagnostic sur base des informations existantes, Etude sur les aspects techniques, économiques et financiers du cadre réglementaire pour la production d'électricité à partir des énergies renouvelables, 14.

Thiam, A., 2015. Rapport de l'étude de marche solaire thermique : production d'eau chaude et de séchage des produits agricoles au Sénégal, 2015, 11-12.
Bilal, B. O., Ndongo, M., Kebe, C.M.F., Sambou, V., Ndiaye, P, A, 2013. Feasibility study of wind energy potential for electricity generation in the northwestern coast of Senegal," Journal of Energy Procedia, 36, 1120 - 1129.

PERACOD, 2011. Les énergies renouvelables les bases, la technologie et le potentiel au Sénégal, 100.

Project, 2012. Projet de construction de la centrale photovoltaïque de bokhol au Senegal, 1-34.

Ten Merina Power plant, 2020. En quelques chiffres, available on :"http ://www.ten-merina.sn/," consulted on 02/09/2020.

Report, 2018. Réalisation d'une revue documentaire sur l'énergie solaire en Afrique de l'Ouest (zone UEMOA) et organisation d'un concours startup. 46 -50 .

Interim report, 2020. Projet de réalisation d'une centrale solaire IPP de 23 MW connectée au réseau existant à Kael (région de Diourbel). 2-317.

Taiba N'Diaye wind farm (158 MW), 2020 Senegal, available on:"https: //www.taibaeolien.com/wpcontent/uploads/2018/12/LekelaSegegal-Taiba N\%E2\%80\%99Diaye-fact-sheet-Nov18-v4.pdf," consulted on 02/09/2020.

Regional off-grid electrification project, 2020. Evaluation du marché de l'énergie solaire hors réseau et conception de dispositifs de soutien au secteur privé. 40.

Berthémaly, J, C., and Vincent N. L'électrification décentralisée dans les pays membres l'UEMOAenjeux, bilan et perspectives. 21.

PNER (National Program of Rural Electrification) du Sénégal, 2020. Projet d'Electrification Rurale par Mini-réseaux solaires de 1000 villages répartis dans sept (07) régions du SENEGAL, 13.

Project PAP2, 2018. Banque de projets du plan d'actions prioritaires du PSE 2020-2023 disponible sur : https://www.aiccopn.pt/archive/doc/PROJETS PAP2 04 Décembre 2018 versionFinale3.pdf consulté le 28/09/2020.

Report annual 2018. Senelec.

CRSE (Commission of Regulation of Electricity Sector), 2020. Révision des conditions tarifaires de Senelec 2020-2022, 22.

Report Senegal, 2020. Evaluation du marché de l'énergie solaire hors réseau et conception de dispositifs de soutien au secteur privé, 44. 


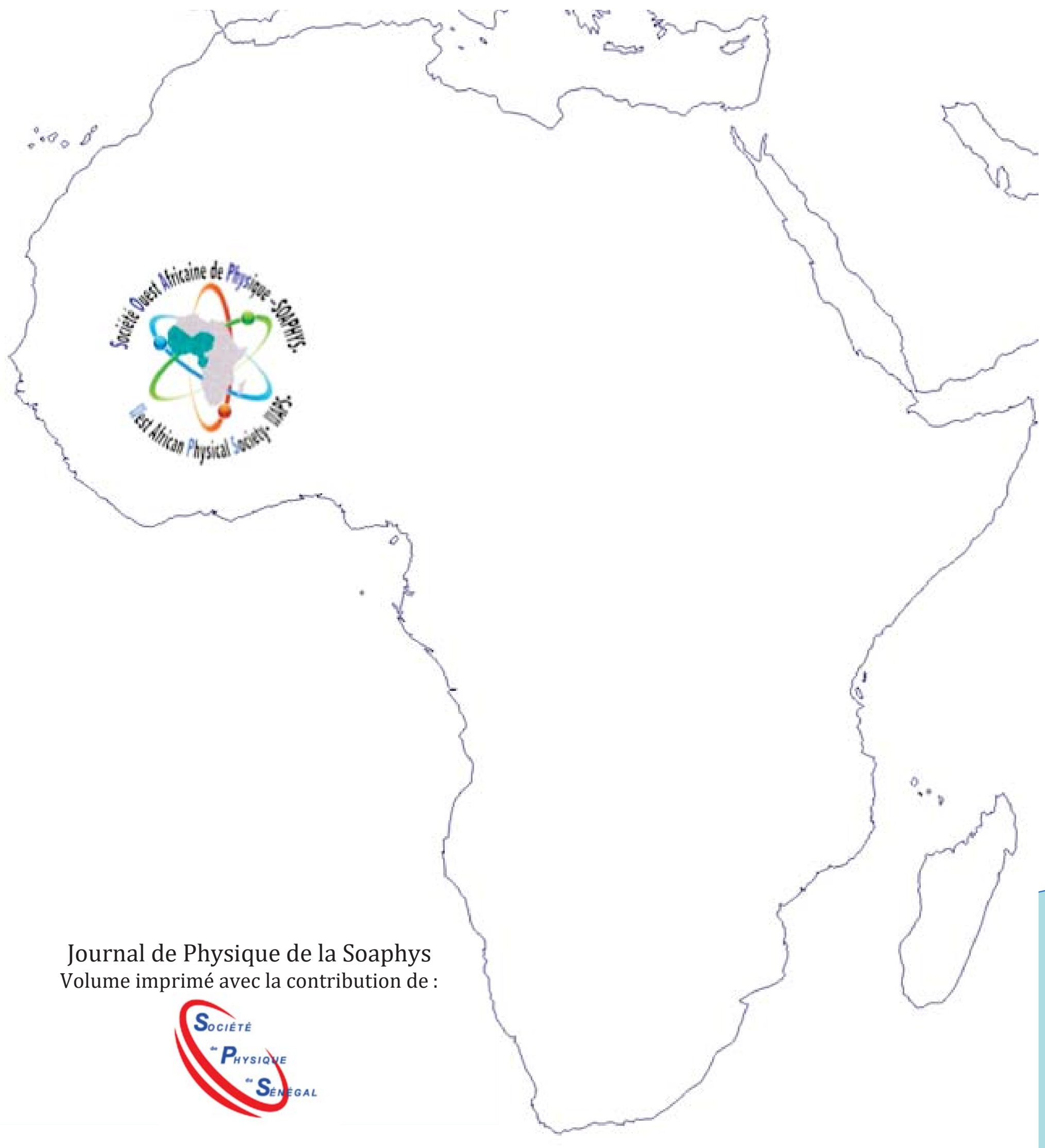

